\title{
RELATION OF RENIN, ANGIOTENSIN II, AND EXPERIMENTAL RENAL HYPERTENSION TO ALDOSTERONE SECRETION *
}

\author{
By CHARLES C. J. CARPENTER, JAMES O. DAVIS ANd CARLOS R. AYERS with \\ THE SURGICAL ASSISTANCE OF ALFRED CASPER
}

(From the Section on Experimental Cardiovascular Disease, Laboratory of Kidney and Electrolyte Metabolism, National Heart Institute, Bethesda, Md.)

(Submitted for publication June 23, 1961 ; accepted July 29, 1961)

Recent studies (1-3) have provided evidence that a humoral substance secreted by the kidney leads to the hypersecretion of aldosterone which occurs after acute hemorrhage, during chronic $\mathrm{Na}$ depletion and during chronic thoracic caval constriction. In subsequent preliminary reports, it has been demonstrated that an aldosterone-stimulating factor is present only in the renin fraction of kidney extracts (4), and that infusions of both renin and angiotensin II result in increased aldosterone output in the dog (5). These findings are consistent with the work of several groups of investigators $(6-12)$, recently summarized by Tobian $(13,14)$, which suggests that the reninangiotensin II system plays an important role in the regulation of aldosterone secretion.

The present series of experiments was designed to test the hypothesis that aldosterone secretion is regulated by the renin-angiotensin II system. In the first two experiments the effects of infusions of renin and of synthetic angiotensin II on the pattern of steroid secretion in dogs were studied at several dosage levels; at the smallest dosage level, angiotensin II was infused at a rate too low to affect arterial blood pressure. To determine whether the steroidogenic effects of these agents are dependent upon ACTH release, all experiments were performed in hypophysectomized animals. In the third experiment, aldosterone and corticosterone secretion rates were determined in conscious, unstressed dogs with experimental benign and malignant renal hypertension, and the relationship between the renin content of the hypertensive kidney and aldosterone output was examined.

\section{MATERIALS AND METHODS}

In Experiment I, six 16 to $20 \mathrm{~kg}$ mongrel dogs were used to study the effects of renin on steroid secretion.

* The present experimental data were presented, in preliminary form, at the meeting of the Federation of the Societies for Experimental Biology in April, 1961.
Each animal was anesthetized with $\mathrm{Na}$ pentobarbital after which hypophysectomy (transbuccal approach), bilateral nephrectomy, and right adrenolumbar vein cannulation were performed. Two hours after hypophysectomy, and approximately 1 hour after nephrectomy, two groups of control samples of adrenal venous blood were collected at 30-minute intervals. All blood collected in these experiments was replaced immediately by homologous transfusion. In one animal, $5 \mathrm{dog}$ units of renin, ${ }^{1}$ prepared from dog kidney by the method of Haas and Goldblatt (16), was injected into a foreleg vein; immediately after the injection an infusion of renin was begun at a rate of $0.1 \mathrm{U}$ per $\mathrm{kg}$ per minute and continued over the following 40 minutes. In the remaining 5 dogs exactly the same procedure was followed, but a smaller amount of renin (2.2 $\mathrm{U}$ as a single initial injection, followed by an infusion of $0.03 \mathrm{U}$ per $\mathrm{kg}$ per minute) was given. At least four $10-\mathrm{ml}$ samples of adrenal effluent were collected from 20 to 40 minutes after the onset of the renin infusion. In 5 of the 6 dogs, additional collections of adrenal venous blood were made 30 to $40 \mathrm{~min}$ utes after completion of the renin infusion.

In Experiment II the effects of angiotensin II were studied in twenty 15 to $20 \mathrm{~kg}$ animals. The dogs were prepared as in Experiment I, except that nephrectomy was performed only in the first 4 and the last 3 dogs of this group. After control collections of adrenal venous blood, angiotensin II in 5 per cent dextrose (valine-5hypertensin II, Ciba) was infused at different dosage levels. In the first $4 \mathrm{dogs}, 20 \mu \mathrm{g}$ of angiotensin II was injected rapidly into a foreleg vein and was followed by an infusion at a rate of $0.25 \mu \mathrm{g}$ per $\mathrm{kg}$ per minute. In 4 of the simple-hypophysectomized ${ }^{2}$ animals, $4.0 \mu \mathrm{g}$ of angiotensin II was given as an initial injection and was followed by an infusion at a rate of $0.05 \mu \mathrm{g}$ per $\mathrm{kg}$ per minute. The remaining 9 simple-hypophysectomized dogs were given no initial injection of angiotensin II and received only infusions at rates of 0.008 to $0.025 \mu \mathrm{g}$ per $\mathrm{kg}$ per minute. The rate of infusion in each dog was slightly less than that which caused the minimal detectable rise

1 As defined by Goldblatt, Katz, Lewis and Richardson, $1 \operatorname{dog} \mathrm{U}$ of renin is that amount which, when injected into a trained, unanesthetized, 10 to $20 \mathrm{~kg}$ dog, results in a maximal increase in mean arterial pressure of 30 $\mathrm{mm} \mathrm{Hg}$ within 3 minutes after the time of injection (15).

2 The "simple-hypophysectomized animal" refers to the dog in which the anterior pituitary has been removed and no other physiological alteration has been made. 
in mean arterial pressure. In addition, angiotensin II infusions at rates of 0.008 to $0.013 \mu \mathrm{g}$ per $\mathrm{kg}$ per minute were given to $3 \mathrm{Na}$-depleted hypophysectomized-nephrectomized dogs; severe $\mathrm{Na}$ depletion in these dogs had been achieved by maintenance on a Na-free diet for 2 weeks, during which time each of the animals had received two injections of $2 \mathrm{ml}$ meralluride sodium (Mercuhydrin) intramuscularly. In each of the 20 dogs, at least 4 samples of adrenal effluent were collected 20 to 40 minutes after the beginning of the angiotensin II infusion. In 2 of the animals which received the largest dose and 2 of the animals which were given the intermediate dose of angiotensin II, further collections of adrenal effluent were made 20 to 30 minutes after the completion of the angiotensin II infusion.

In both Experiments I and II, aortic blood pressures were measured by means of indwelling polyethylene catheters and Statham strain gage transducers and recorded continuously on a Sanborn recorder. Aldosterone and corticosterone secretion rates were determined by methods described previously (17), with the double isotope derivative technique of Kliman and Peterson (18). Silber-Porter chromogens were measured by a modification of the technique described by Peterson, Karrer and Guerra (19).

In Experiment III, 15 trained 16 to $20 \mathrm{~kg}$ mongrel dogs were used. All animals received (by force feeding when necessary) a synthetic diet containing $60 \mathrm{mEq} \mathrm{Na}$ and $18 \mathrm{mEq} \mathrm{K}$ per day throughout the period of study. Control blood pressures were measured in the trained, unanesthetized animals by direct femoral arterial puncture with a 20 gage needle connected to a Statham strain gage transducer, and mean arterial pressures were determined and recorded by a Sanborn recording system. After control blood pressure measurements over a 1 to 3 week period, a Goldblatt clamp was placed on the left renal artery of each dog, by the technique of Goldblatt (20). Five to 10 days after left renal arterial constriction a similar clamp was plared on the right renal artery. In the last 6 dogs of the group, in an attempt to produce the experimental malignant hypertensive syndrome, the degree of renal arterial constriction was increased to such an extent that the pulse in the renal artery distal to the Goldblatt clamp was approximately one-fourth of that proximal to the clamp, as determined by digital palpation. In 7 of the 15 animals, serum $\mathrm{Na}$ and $\mathrm{K}$ determinations were performed by flame photometry both during the control period and 4 to 14 days after application of the second Goldblatt clamp. At intervals varying from 3 days to 3 weeks after the second Goldblatt clamp had been applied, a polyvinyl catheter was placed in the right adrenolumbar vein of each animal under sterile conditions, and three $10-\mathrm{ml}$ samples of adrenal venous blood were obtained.

In 9 of these 15 animals, collections of adrenal effluent were made daily for periods of 3 to 13 days from the conscious, unstressed animal via the chronic indwelling adrenal venous catheter. In one of the animals, the right adrenal venous catheter was removed after 2 weeks of daily collections. In this dog blood pressure measure- ments were continued over the following 8 weeks, at the end of which time a chronic catheter was placed in the left adrenolumbar vein, by the technique of Hume and Nelson (21); further collections of adrenal effluent were made daily over the following week. Each animal was given 3,000 USP units of heparin immediately before each collection of adrenal venous blood. Since several of the hypertensive animals bled intermittently into the laparotomy site for the first 2 or 3 days after surgery, hematocrits were determined daily throughout the period of study, and each animal received homologous blood transfusions in such quantity as was necessary to maintain the hematocrit at the control level. Because of the well recognized effect of blood loss on steroid production $(22,23)$, aldosterone and corticosterone secretion rates for each dog were determined only on those days on which the hematocrit approximated the control level.

Four of the animals with benign renal hypertension were anesthetized with $\mathrm{Na}$ pentobarbital at intervals of $15,16,60$, and 90 days, respectively, after the application of the second Goldblatt clamp, and the kidneys were rapidly removed and frozen at $-20^{\circ} \mathrm{C}$; care was taken to avoid blood loss during removal of the kidneys. The kidneys were also removed from 4 of the dogs with malignant hypertension as soon as possible after the death of the animal; the interval between application of the second Goldblatt clamp and removal of the kidneys varied from 7 to 17 days in these animals. At intervals of 2 to 6 months after freezing, the kidneys were thawed in a water bath at room temperature, and renin was extracted by a modification of the technique of Haas and Goldblatt (16). The modification consisted in acidifying the extract to $\mathrm{pH} 2.75$ (instead of $\mathrm{pH} 2.60$ ), as this was the $\mathrm{pH}$ level at which the maximal yield of renin was obtained from normal dog kidneys in our laboratory. The $\mathrm{pH}$ was determined with a model 76 Beckman expanded scale $\mathrm{pH}$ meter. Renin extractions of both kidneys of one benign and one malignant hypertensive dog were always performed simultaneously. Assays of the potency of each sample of renin were performed in duplicate or triplicate, with a modification of the technique described by Goldblatt and colleagues (15). The modification consisted in measuring arterial blood pressure by direct femoral arterial puncture with a 20 gage needle attached to a Statham strain gage transducer, and determining mean arterial pressure on a Sanborn recording system.

\section{RESULTS}

\section{Effects of renin on steroid secretion in hypophy- sectomized-nephrectomized dogs}

In each animal the control aldosterone, corticosterone and Porter-Silber chromogen secretion rates were in the range previously observed in hypophysectomized-nephrectomized dogs $(1,3)$ (Table I, see Figure 1). Injection of $5 \mathrm{dog} U$ of renin followed by infusion of renin at a rate of $0.1 \mathrm{U}$ per $\mathrm{kg}$ per minute (Figure 1) re- 
TABLE I

Effects of renin* on adrenocortical steroid secretion in hypophysectomized-nephrectomized dogs

\begin{tabular}{|c|c|c|c|c|c|c|c|c|c|}
\hline \multirow[b]{3}{*}{ Dog } & \multirow{2}{*}{\multicolumn{2}{|c|}{$\begin{array}{l}\text { Aldosterone } \\
\text { secretion }\end{array}$}} & \multirow{2}{*}{\multicolumn{2}{|c|}{$\begin{array}{l}\text { Corticosterone } \\
\text { secretion }\end{array}$}} & \multirow{2}{*}{\multicolumn{2}{|c|}{$\begin{array}{c}\text { Porter-Silber } \\
\text { chromogen } \\
\text { secretion }\end{array}$}} & \multicolumn{3}{|c|}{$\underset{\text { pressuret }}{\text { Mean arterial blood }}$} \\
\hline & & & & & & & \multirow[b]{2}{*}{ Betort } & \multirow{2}{*}{$\begin{array}{l}2 \mathrm{~min} \\
\text { after } \\
\text { initial } \\
\text { injection }\end{array}$} & \multirow{2}{*}{$\begin{array}{l}\text { During } \\
\text { infusion }\end{array}$} \\
\hline & Before & During & Before & During & Before & During & & & \\
\hline & \multicolumn{2}{|c|}{$\mu g / \min$} & \multicolumn{2}{|c|}{$\mu g / \min$} & \multicolumn{2}{|c|}{$\mu g / \min$} & \multicolumn{3}{|c|}{$m m H_{g}$} \\
\hline 1 & 0.001 & 0.006 & 0.01 & 0.05 & $0.15^{\mu t}$ & 0.05 & 60 & 136 & 146 \\
\hline 2 & .005 & .017 & .16 & .18 & .15 & .23 & 35 & 82 & 82 \\
\hline 3 & .011 & .037 & .09 & .73 & .16 & .52 & 50 & 95 & 92 \\
\hline 4 & .016 & .027 & .02 & .18 & .12 & .15 & 60 & 90 & 98 \\
\hline 5 & .004 & .008 & .01 & .09 & .03 & .06 & 80 & 130 & 130 \\
\hline Average & .007 & .019 & .06 & .25 & .12 & .20 & $5 i$ & 107 & 110 \\
\hline
\end{tabular}

* In this series of dogs an initial intravenous injection of $2.2 \mathrm{dog}$ units of renin was followed by an infusion of renin at a rate of $0.03 \mathrm{U} / \mathrm{kg} / \mathrm{minute}$.

t Values for mean arterial pressure during infusion represent average pressures during the 40 -minute period of renin infusion. Note that the blood pressure elevation was sustained throughout the period of renin infusion in every animal.

sulted in a striking increase in secretion rates of each of the steroids studied; the relative increases in aldosterone (4-fold) and corticosterone output (5-fold) were greater than the increment in Porter-Silber chromogen produc- tion (2-fold). Despite an increase in mean arterial pressure from 70 to $130 \mathrm{~mm} \mathrm{Hg}$, adrenal blood flow was not altered during the renin infusion. During administration of the lower dose of renin (2.2 $\mathrm{U}$ as an initial injection, followed by in-

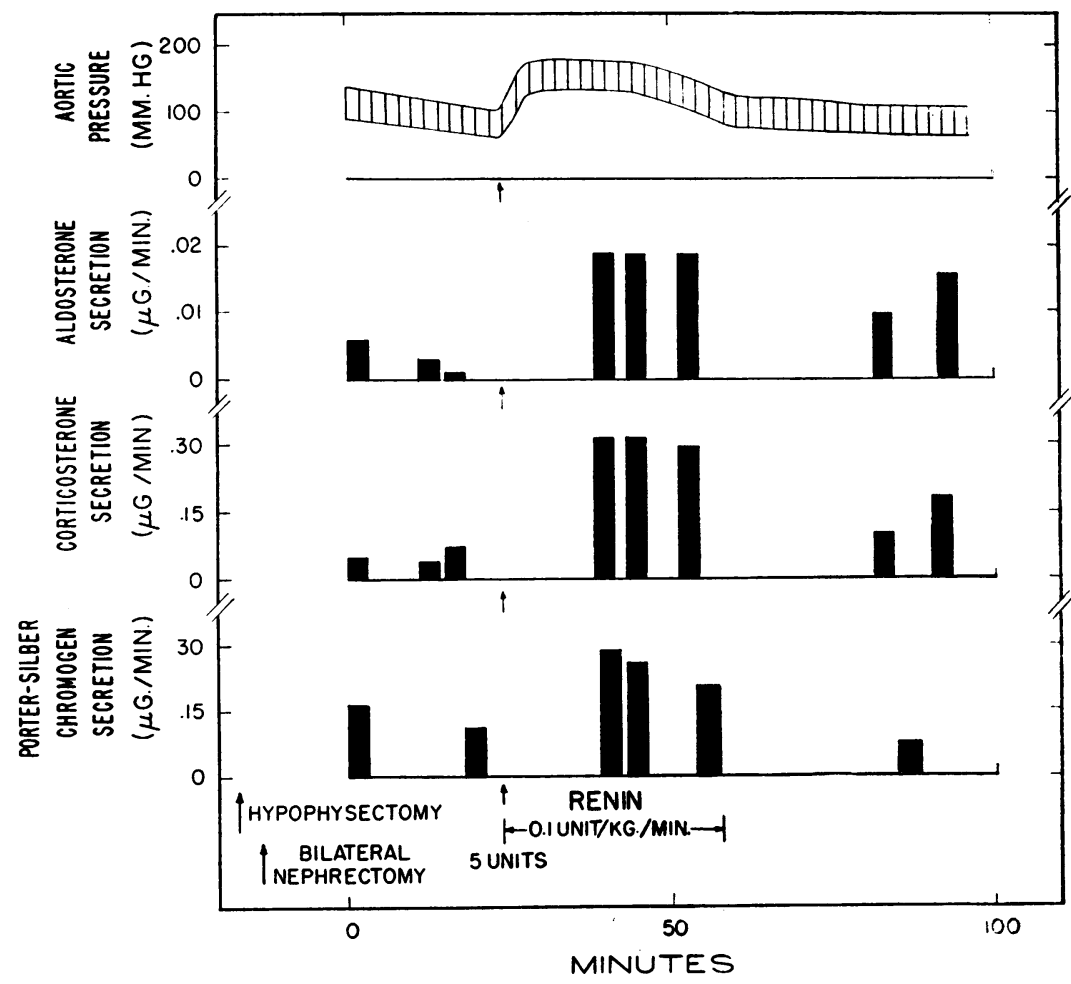

Fig. 1. EfFects of Renin on arterial blood pressure, and oN SECretron rates of aldosterone, corticosterone and Porter-Silber chromogens in A H YPOPH YSECTOMIZED-NEPHRECTOMIZED DOG. 


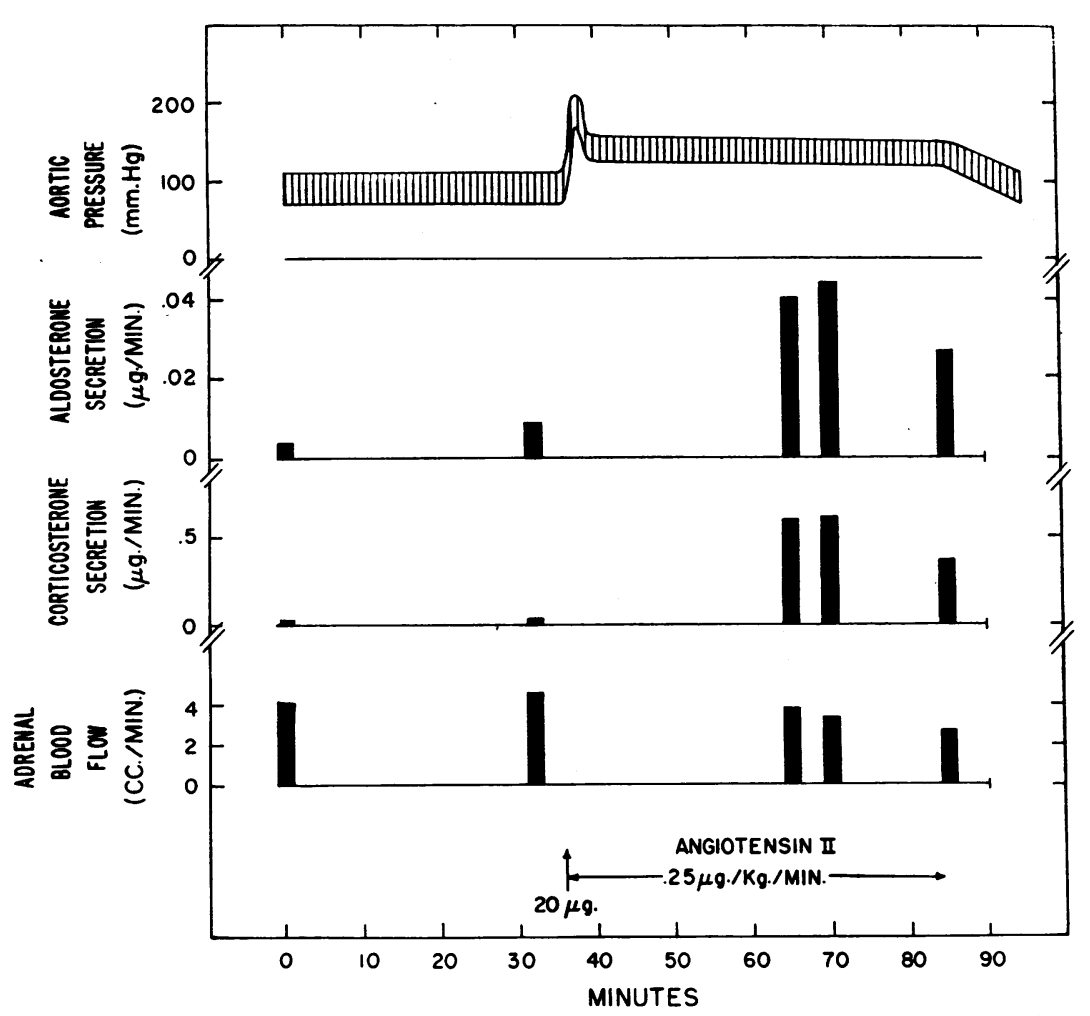

Fig. 2. EFFECTS OF ANGIOTENSIN II ON ARTERIAL BLOOD PRESSURE, ALDOSTERONE AND CORTICOSTERONE SERETION RATES AND ADRENAL BLOOD FLOW IN A HYPOPHYSECTOMIZED-XEPHRECTOMIZED DOG.

fusion at a rate of $0.03 \mathrm{C}$ per $\mathrm{kg}$ per minute), aldosterone secretion increased in all 5 dogs, with an average increment of 172 per cent for the group; corticosterone output increased in 4 of the 5 dogs, with an average 316 per cent rise; and Porter-Silber chromogens increased in 3 of the 5 dogs, with an average increment of 67 per cent. A slight increase in adrenal blood flow was observed in 3 of the 5 dogs during the renin infusion. Secretion rates of each of the steroids had decreased, but had not returned to control levels, within 30 minutes after completion of the renin infusion in each of the 5 animals. In each animal the injection of renin resulted in a marked rise in mean arterial pressure, with an average increase of $50 \mathrm{~mm} \mathrm{Hg}$ for the group of 5 dogs; the blood pressure remained at the elevated level throughout the period of renin infusion (Table I). After completion of the renin infusion, mean arterial pressure gradually returned to control levels over a 15 to 30 minute period.
Effects of infusion of angiotensin II at three dosage levels

A. High dosage level; $20 \mu \mathrm{g}$ initially, followed by infusion at a rate of $0.25 \mu \mathrm{g}$ per $\mathrm{kg}$ per minute into hypophysectomized-nephrectomized dogs. Increments in secretion of each of the steroids occurred, and marked increases in mean arterial pressure were observed in all 4 dogs. The average aldosterone output for the group increased from 0.004 to $0.021 \mu \mathrm{g}$ per minute, a 425 per cent increment (Figure 2 and Dogs $1-4$ of Table II). The average corticosterone secretion rate showed a 33-fold rise (Figure 2 and Table II). The average Porter-Silber chromogen production increased 375 per cent (Table II). Although the absolute increase was not so great for aldosterone as for corticosterone, the average level of aldosterone secretion during angiotensin II infusion was essentially the same as that observed in normal dogs stressed by laparotomy (17), whereas the experimental values for corticosterone (with 
one exception, Dog 2 of Table II) and PorterSilber chromogens remained far below the average values observed in stressed normal dogs (17). In the two animals in which adrenal effluent was collected at intervals after completion of the angiotensin II infusion, a sharp decrease in the secretion rates of all three steroids was observed within 30 minutes. Mean arterial pressure reached a maximum 30 to 45 seconds after the initial injection of angiotensin II and thereafter showed a gradual decline throughout the period of angiotensin II infusion. This slow decline in blood pressure probably reflects the progressive loss of vigor in these hypophysectomized dogs which were subjected to extensive surgery. Within 5 minutes after completion of the infusion, blood pressure had fallen below the initial control levels in all animals. Adrenal blood flow was not altered by angiotensin II ; for the group of 4 dogs, the average adrenal blood flow was $3.4 \mathrm{ml}$ per minute for the control period and $3.3 \mathrm{ml}$ per minute during the angiotensin II infusion.

$B$. Intermediate dosage level; injection of $4 \mu \mathrm{g}$ angiotensin $I I$, followed by infusion at a rate of $0.05 \mu \mathrm{g}$ per $\mathrm{kg}$ per minute into simple-hypophysectomized dogs. Aldosterone output increased in 3 of the 4 dogs, corticosterone production was augmented in all animals, and the Porter-Silber chromogen secretion rate increased in 3 of the 4 dogs (Table II). The average increment in secretion

TABLE II

Effects of angiotension II on adrenocortical steroid secretion and arterial blood pressure in dogs

\begin{tabular}{|c|c|c|c|c|c|c|c|c|c|c|c|c|}
\hline \multirow[b]{2}{*}{ Dog } & \multirow[b]{2}{*}{$\begin{array}{l}\text { Type of } \\
\text { preparation* }\end{array}$} & \multicolumn{2}{|c|}{$\begin{array}{l}\text { Quantity of } \\
\text { angiotensin II } \\
\text { injected }\end{array}$} & \multicolumn{2}{|c|}{$\begin{array}{l}\text { Aldosterone } \\
\text { secretion } \dagger\end{array}$} & \multicolumn{2}{|c|}{$\begin{array}{l}\text { Corticosterone } \\
\text { secretion† }\end{array}$} & \multicolumn{2}{|c|}{$\begin{array}{l}\text { Porter-Silber } \\
\text { chromogen } \\
\text { secretion }\end{array}$} & \multicolumn{3}{|c|}{$\begin{array}{c}\text { Mean arterial blood } \\
\text { pressuret }\end{array}$} \\
\hline & & Start & Infusion & Before & During & Before & During & Before & During & Before & $\begin{array}{l}30 \mathrm{sec} \\
\text { after }\end{array}$ & $\begin{array}{l}\text { During } \\
\text { infusion }\end{array}$ \\
\hline \multirow{6}{*}{$\begin{array}{r}1 \\
2 \\
3 \\
4 \\
\text { Avg. } \\
1-4\end{array}$} & \multirow{6}{*}{$\begin{array}{l}\mathrm{H}-\mathrm{N} \\
\mathrm{H}-\mathrm{N} \\
\mathrm{H}-\mathrm{N} \\
\mathrm{H}-\mathrm{N}\end{array}$} & $\mu g$ & $\mu \mathrm{g} / \mathrm{kg} / \min$ & \multicolumn{2}{|c|}{$\mu \mathrm{g} / \min$} & \multicolumn{2}{|c|}{$\mu g / \min$} & \multicolumn{2}{|c|}{$\mu g / \min$} & \multicolumn{3}{|c|}{$m m \mathrm{Hg}$} \\
\hline & & 20 & 0.250 & 0.001 & 0.018 & 0.01 & 0.09 & 0.03 & 0.11 & 75 & 125 & 120 \\
\hline & & 20 & .250 & .006 & .010 & .04 & 1.78 & .07 & .71 & 100 & 140 & 136 \\
\hline & & 20 & .250 & .001 & .015 & .01 & .17 & .12 & .17 & 125 & 205 & 140 \\
\hline & & 20 & .250 & .007 & .042 & .01 & .62 & .01 & .17 & 80 & 180 & 145 \\
\hline & & 20 & .250 & .004 & .021 & .02 & .67 & .06 & .29 & 95 & 163 & 135 \\
\hline 5 & S-H & 4 & 050 & .002 & .012 & .05 & 23 & .02 & .09 & 50 & 100 & 50 \\
\hline 6 & S-H & 4 & .050 & .001 & .007 & .02 & .12 & .05 & .06 & 90 & 155 & 115 \\
\hline 7 & S-H & 4 & .050 & .006 & .008 & .37 & .64 & .23 & .26 & 105 & 130 & 123 \\
\hline 8 & S-H & 4 & .050 & .012 & .024 & .03 & .16 & .02 & .10 & 85 & 132 & 108 \\
\hline Avg. & & 4 & .050 & .005 & .013 & .12 & .29 & .08 & .13 & 83 & 129 & 99 \\
\hline 9 & S-H & 0 & .025 & .014 & .019 & .25 & .68 & .07 & .31 & 120 & & 120 \\
\hline 10 & S-H & 0 & .021 & .002 & .007 & .07 & .09 & .01 & .01 & 82 & & 82 \\
\hline 11 & S-H & 0 & .013 & .004 & .009 & .01 & .07 & .01 & .01 & 75 & & 73 \\
\hline 12 & S-H & 0 & .013 & .003 & .003 & .01 & .01 & .01 & .01 & 126 & & 136 \\
\hline 13 & S-H & 0 & .013 & .030 & .022 & .11 & .19 & .10 & .12 & 118 & & 118 \\
\hline 14 & S-H & 0 & .013 & .003 & .003 & .14 & .30 & .04 & .11 & 132 & & 124 \\
\hline 15 & S-H & 0 & .013 & .004 & .006 & .19 & .29 & .05 & .16 & 124 & & 134 \\
\hline 16 & S-H & 0 & .013 & .007 & .013 & .02 & .04 & .01 & .03 & 105 & & 108 \\
\hline 17 & S-H & 0 & .008 & .003 & .026 & .04 & .26 & .11 & .10 & 105 & & 100 \\
\hline \multirow{2}{*}{ Avg. } & & & & & & & & & & & & \\
\hline & & 0 & .015 & .008 & .011 & .09 & .21 & .05 & .10 & 110 & & 111 \\
\hline \multirow{4}{*}{$\begin{array}{c}18 \\
19 \\
20 \\
\text { Avg. } \\
18-20\end{array}$} & low Na-H-N & 0 & .013 & .010 & .007 & .01 & .02 & .08 & .06 & 96 & & 95 \\
\hline & low Na-H-N & 0 & .013 & .007 & .008 & .01 & .01 & .11 & .04 & 158 & & 166 \\
\hline & low Na-H-N & $\mathbf{0}$ & .008 & .011 & .013 & .01 & .01 & .03 & .05 & 96 & & 110 \\
\hline & & 0 & .011 & .009 & .009 & .01 & .01 & .07 & .05 & 117 & & 124 \\
\hline
\end{tabular}

${ }^{*} \mathrm{H}-\mathrm{N}$, hypophysectomized-nephrectomized preparation; S-H, simple-hypophysectomized dog; low Na-H-N indicates animals which had been on a Na-free diet for 2 weeks, had been hypophysectomized for 3 days, and underwent bilateral nephrectomy 1 hour prior to the present acute study.

$\dagger$ Each value for aldosterone or corticosterone secretion represents the average of 2 or 3 determinations performed on separate samples of adrenal venous blood.

$\ddagger$ "30 sec after" refers to the maximal mean arterial pressure 30 seconds after the starting dose of angiotensin II. "During infusion" indicates the average mean arterial pressure for the 40 -minute period during which the angiotensin II was infused. 
rate of each of the steroids ( 160 per cent for aldosterone, 142 per cent for corticosterone, 50 per cent for Porter-Silber chromogens) was less than that observed after the larger dose of angiotensin II was given to nephrectomized-hypophysectomized dogs; however, the reduction in increment in aldosterone secretion was not nearly so great as the decrease in increment in corticosterone output, and was also less than the reduction in increment in Porter-Silber chromogen production (Table II). The increases in steroid secretion rates during administration of angiotensin II at this dosage level were comparable in magnitude with the increases observed during infusion of renin at the rate described above. In the two animals in which postinfusion studies were made, secretion rates of aldosterone and corticosterone had decreased but had not returned to control levels within 20 minutes after completion of the angiotensin II infusion. Infusion of angiotensin II at this dosage level resulted in increases in mean arterial pressure in all animals, but the initial increases were not so marked as during administration of the larger dose to hypophysectomizednephrectomized dogs, and the elevations of arterial pressure were not maintained throughout the period of study (Dogs 5-8, Table II). Adrenal blood flow showed no consistent changes during the angiotensin II infusion.

C. Low dosage level; infusion of angiotensin II at 0.008 to $0.025 \mu \mathrm{g}$ per $\mathrm{kg}$ per minute. When angiotensin II was infused into 9 simple-hypophysectomized dogs at a rate slightly less than that which caused the minimal detectable increase in mean arterial pressure (no initial injection of angiotensin II was given) variable results were obtained (Dogs 9-17, Table II). Both dogs which received infusions at a rate of 0.025 and $0.021 \mu \mathrm{g}$ per $\mathrm{kg}$ per minute showed increases in aldosterone secretion rates (Dogs 9 and 10, Table II). Of the 7 dogs given infusions at rates of 0.008 to $0.013 \mu \mathrm{g}$ per $\mathrm{kg}$ per minute, three (Dogs 11, 16 and 17) showed an increase in aldosterone, while 5 animals $(11,13,14,15$ and 17, Table II) responded with increases in corticosterone output; definite increases in Porter-Silber chromogen production occurred in 2 of the 7 dogs (14 and 15, Table II). However, it is noteworthy that the animal (Dog 17, Table II), which received angiotensin II at the lowest rate of infusion, showed unequivocal increases in both aldosterone and corticosterone production. For the group of 7 dogs given angiotensin II at rates of 0.008 to $0.013 \mu \mathrm{g}$ per $\mathrm{kg}$ per minute, the increase in aldosterone production was not statistically significant $(t, 1.32 ; \mathrm{p}>0.2)$, while a significant increase in the secretion rate of corticosterone $(t, 3.13 ; \mathrm{p}<$ 0.02 ) occurred. No significant change in PorterSilber chromogen output was observed at this dosage level $(t, 1.74 ; \mathrm{p}>0.1)$. Mean arterial blood pressure remained essentially unchanged $(t, 0.37 ; \mathrm{p}>0.9)$ during the angiotensin II infusion in these animals. Adrenal blood flow showed little variation during the period of study in any of the 9 dogs in this group.

Infusion of angiotensin II at rates of 0.008 to $0.013 \mu \mathrm{g}$ per $\mathrm{kg}$ per minute into 3 hypophysectomized-nephrectomized dogs, pretreated by 2 weeks on a Na-free diet, did not affect the low basal rates of secretion of aldosterone, corticosterone or Porter-Silber chromogens in any animal (Dogs 18-20, Table II). It should be emphasized that all values for aldosterone and corticosterone secretion represent the average of two or three determinations from separate collections of adrenal vein blood.

\section{Aldosterone secretion in experimental renal hy- pertension}

An increase in mean arterial pressure was observed in every dog within 1 week after the left (first) Goldblatt clamp had been placed; the average increase in mean arterial pressure at this time was $26 \mathrm{~mm} \mathrm{Hg}$, with a range of 10 to 47 . In each dog a further increase in arterial pressure was observed after the application of the second Goldblatt clamp. The behavior of the dogs after constriction of the right (second) renal artery followed one of two general patterns. In the first group of dogs (1-8, Table III), each animal, despite the development of sustained moderate to severe hypertension, continued to appear healthy and to eat well (with one exception, Dog 6 of Tables III and V, which is discussed below), and all animals survived until they were sacrificed to obtain the kidneys for renin assays; the group of dogs was considered to have benign renal hypertension. The second group (Dogs 9-15, Table IV) exhibited progressive weakness, lethargy, anorexia and preterminal vomiting, and died from 
TABLE III

Adrenocortical steroid secretion in dogs with experimental benign renal hypertension

\begin{tabular}{|c|c|c|c|c|c|}
\hline \multirow[b]{2}{*}{ Dog } & \multirow{2}{*}{$\begin{array}{l}\text { Aldosterone } \\
\text { secretion }\end{array}$} & \multirow{2}{*}{$\begin{array}{c}\text { Corticosterone } \\
\text { secretion }\end{array}$} & \multicolumn{2}{|c|}{$\begin{array}{c}\text { Avg. mean arterial } \\
\text { pressure* }\end{array}$} & \multirow{2}{*}{$\begin{array}{c}\text { Duration, } \\
\text { bilat. rena } \\
\text { art. } \\
\text { constrict. } \uparrow\end{array}$} \\
\hline & & & Control & $\overline{\text { Exp. }}$ & \\
\hline & $\mu \mathrm{g} / \min$ & $\mu g / \min$ & \multicolumn{2}{|c|}{$\mathrm{mm} \mathrm{Hg}$} & days \\
\hline 1 & 0.012 & 1.70 & 137 & 220 & 4 \\
\hline 2 & .018 & 1.62 & 118 & $180^{-}$ & 3 \\
\hline 3 & .042 & 3.80 & 133 & 199 & 12 \\
\hline 4 & .028 & 2.34 & 133 & 180 & 13 \\
\hline 5 & .011 & 1.28 & 124 & 185 & 24 \\
\hline 6 & .065 & 3.07 & 121 & 192 & 4 \\
\hline 7 & .021 & 3.29 & 131 & 187 & 4 \\
\hline 8 & .023 & 2.82 & 128 & 190 & 6 \\
\hline Average & .028 & 2.49 & 129 & 192 & 9 \\
\hline $\begin{array}{l}\text { Normal dogs } \\
\text { stressed by } \\
\text { laparotomy } \\
n=26\end{array}$ & $\begin{array}{r}0.024 \\
\pm 0.017\end{array}$ & $\begin{array}{r}2.34 \\
\pm 0.84\end{array}$ & & & \\
\hline
\end{tabular}

* Values represent the average mean arterial pressures during the 4-week period after application of the second Goldblatt clamp.

$\dagger$ Number of days after second Goldblatt clamp was placed. The first Goldblatt clamp was placed 1 to 2 weeks before the second.

7 to 21 days after constriction of the second renal artery; this group of animals was considered to have malignant renal hypertension. These two groups will be considered separately.

For the dogs with benign hypertension, the average mean arterial pressure during the 4-week period following constriction of the second renal artery was $192 \mathrm{~mm} \mathrm{Hg}$, representing a 49 per cent increase over the average control value. Serum $\mathrm{Na}$ and $\mathrm{K}$ concentrations remained es- sentially unchanged after the development of hypertension in the 3 animals in which electrolyte determinations were made. At the time of laparotomy the aldosterone secretion rates ranged from 0.011 to $0.065 \mu \mathrm{g}$ per minute; in only one (Dog 6 of Table III) did the aldosterone output significantly exceed the average value observed in normal dogs stressed by laparotomy. The average value for the group of 8 dogs was $0.028 \mu \mathrm{g}$ per minute (Table III); this value does not differ

TABLE IV

Adrenocortical steroid secretion in dogs with experimental malignant renal hypertension

\begin{tabular}{|c|c|c|c|c|c|}
\hline \multirow[b]{2}{*}{ Dog } & \multirow{2}{*}{$\begin{array}{c}\text { Aldostrone } \\
\text { secretion }\end{array}$} & \multirow{2}{*}{$\begin{array}{c}\text { Corticosterone } \\
\text { secretion }\end{array}$} & \multicolumn{2}{|c|}{$\begin{array}{l}\text { Avg. mean arterial } \\
\text { pressure* }\end{array}$} & \multirow{2}{*}{$\begin{array}{c}\text { Duration, } \\
\text { bilat. renal } \\
\text { art. } \\
\text { constrict. } \dagger\end{array}$} \\
\hline & & & Control & Exp. & \\
\hline & $\mu g / \min$ & $\mu g / \min$ & \multicolumn{2}{|c|}{$m m \mathrm{Hg}$} & days \\
\hline 9 & 0.047 & 2.95 & 115 & 212 & 19 \\
\hline 10 & .053 & 2.26 & 125 & 200 & 6 \\
\hline 11 & .041 & 2.43 & 134 & 212 & 4 \\
\hline 12 & .044 & 0.29 & 118 & 188 & 3 \\
\hline 13 & .066 & 1.78 & 121 & 199 & 3 \\
\hline 14 & .043 & 4.19 & 132 & 184 & 6 \\
\hline 15 & . .168 & 2.07 & 124 & 203 & 3 \\
\hline Average & .066 & 2.28 & 124 & 200 & 6 \\
\hline Normal dogs & & & & & \\
\hline stressed by & 0.024 & 2.34 & & & \\
\hline $\begin{array}{l}\text { laparotomy } \\
\mathrm{n}=26\end{array}$ & \pm 0.017 & \pm 0.84 & & & \\
\hline
\end{tabular}

* Values represent the maximal arterial pressures observed prior to the animals' demise.

$\dagger$ Number of days after second Goldblatt clamp was placed. The first Goldblatt clamp was placed 1 to 2 weeks before the second. 


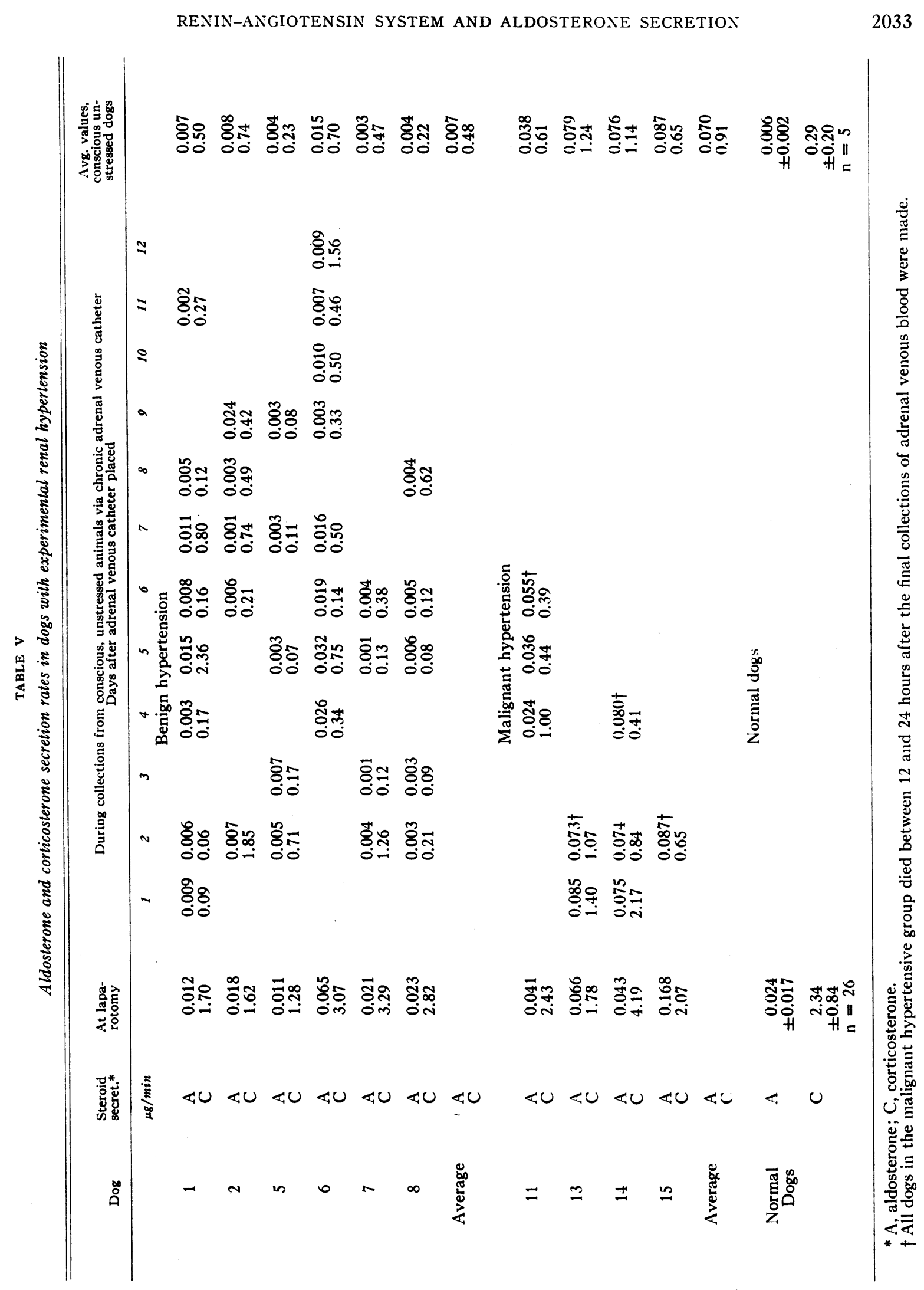




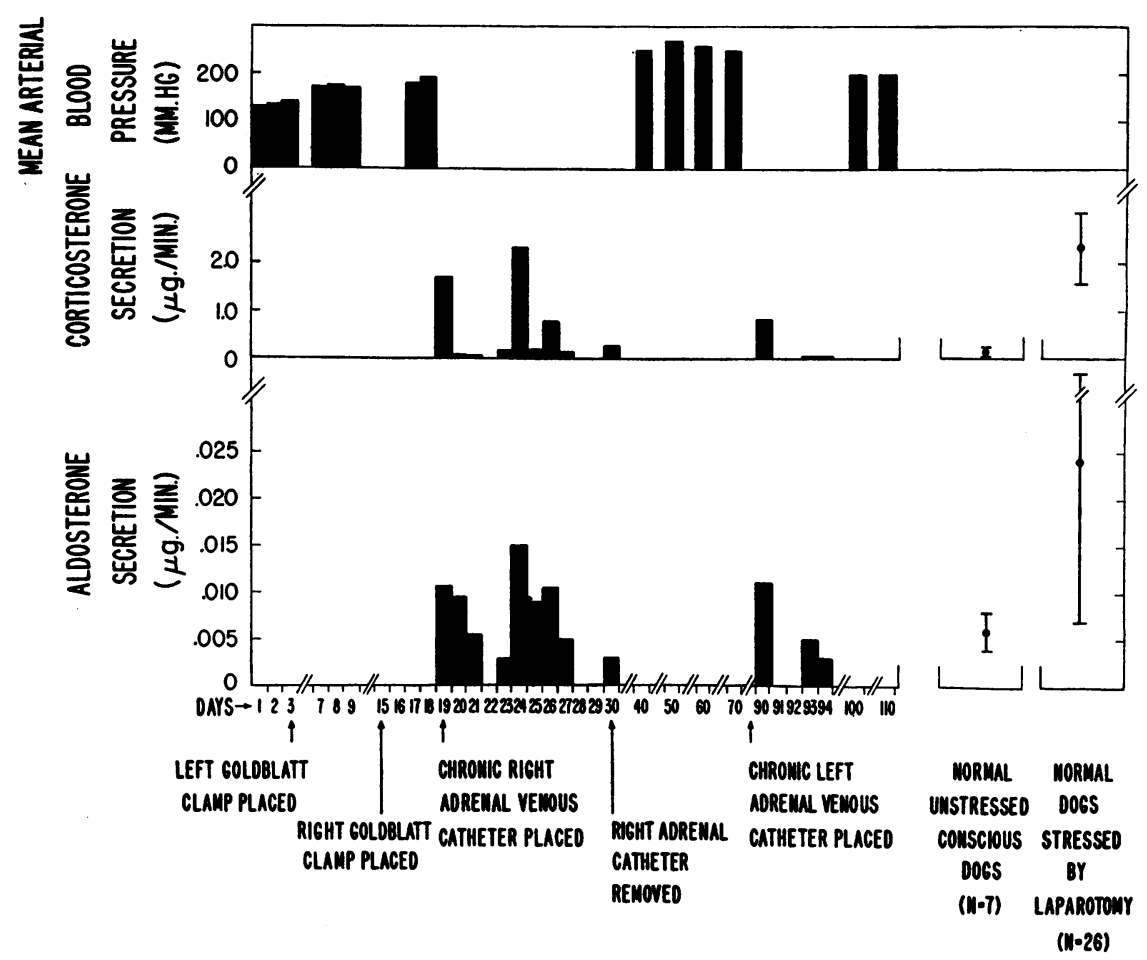

Fig. 3. Aldosterone and corticosterone secretion rates and mean arterial PRESSURE IN A DOG WITH BENIGN RENAL HYPERTENSION. Note that the average rate of aldosterone secretion is essentially the same as that observed in normal conscious dogs, and that the aldosterone output exceeds $0.010 \mu \mathrm{g}$ per minute only on those days on which the simultaneous corticosterone secretion rates are elevated above the basal level (Dog 1 of Tables III and V).

significantly from the average aldosterone secretion rate of $0.024 \pm 0.017 \mu \mathrm{g}$ per minute SD observed in 26 normal dogs stressed by laparotomy $(t, 0.57 ; \mathrm{p}>0.5)$. The average corticosterone secretion rate for the group of 8 dogs at the time of laparotomy was $2.49 \mu \mathrm{g}$ per minute, which is essentially the same as the average value of 2.34 $\pm 0.84 \mu \mathrm{g}$ per minute SD observed in 26 normal dogs stressed by laparotomy $(t, 0.57 ; \mathrm{p}>0.5)$. The mean adrenal blood flow of $4.0 \mathrm{ml}$ per minute was greater than the average value of 2.9 for normal stressed dogs, but the difference is not statistically significant $(t, 1.93 ; \mathrm{p}>0.05)$.

In 6 dogs of this group $(1,2,5-8$, Tables III and V) adrenal venous blood was collected at intervals over a 7 to 12 day period, via an indwelling adrenal venous catheter, while the animals were in a conscious, unstressed state. In these animals the average aldosterone secretion rate was $0.007 \mu \mathrm{g}$ per minute, a value that agrees closely with the average output of $0.006 \pm 0.002 \mu \mathrm{g}$ per minute reported for normal, unstressed conscious dogs (24). The average corticosterone secretion rate for this same period was $0.48 \mu \mathrm{g}$ per minute, which is not significantly different from the value of $0.29 \pm 0.20 \mu \mathrm{g}$ per minute SD observed in normal unstressed, conscious dogs $(t, 1.42 ; \mathrm{p}>0.1)$. In the dog (Figure 3, Dog 1 of Tables III and V) in which subsequent secretion studies were made 3 months after application of the second Goldblatt clamp by placing an indwelling catheter in the left adrenolumbar vein, the average secretion rates for aldosterone and corticosterone were. $0.007 \mu \mathrm{g}$ per minute and $0.29 \mu \mathrm{g}$ per minute, respectively. In the one animal in which the aldosterone secretion rate during laparotomy appeared to be significantly elevated (Dog 6 of Tables III and $\mathrm{V}$ ), the aldosterone output remained quite high during the first week after placement of the indwelling adrenal catheter, but was consistently within normal limits during the second week of studies in the conscious animal; the corticosterone 
secretion rate showed no significant change during this time (Table V). In the remaining 5 dogs of this group the aldosterone secretion rate exceeded $0.010 \mu \mathrm{g}$ per minute on only four occasions (Day 9 for Dog 2 of Table V, and Days 5, 7 and 72 after the catheter was placed in Dog 1 of Table V and Figure 3). On two of the four days on which the aldosterone output exceeded 0.010 $\mu \mathrm{g}$ per minute, the simultaneous corticosterone secretion rate was greater than $1.80 \mu \mathrm{g}$ per minute (Figure 3 ); these very high values for corticosterone output probably reflect a greater than basal rate of release of ACTH. It is suggested that the slightly higher aldosterone secretion rates on these days were secondary to increased ACTH release and did not result from increased secretion of the renal aldosterone-stimulating substance. The rate of corticosterone secretion during infusion of angiotensin II was considerably less than $1.80 \mu \mathrm{g}$ per minute during aldosterone secretion rates of the magnitude ( 0.010 to $0.015 \mu \mathrm{g}$ per minute) observed here.

For the group of 7 dogs (9-15, Table IV) with malignant hypertension, the blood pressure increased more rapidly after constriction of the right (second) renal artery. The average of the maximal observed mean arterial pressures for this group of dogs was $200 \mathrm{~mm} \mathrm{Hg}$, representing a 61 per cent increase over the control value. No significant changes in serum $\mathrm{Na}$ and $\mathrm{K}$ levels were observed after the development of hypertension in any of the four animals in which electrolyte determinations were made. The explanation for this finding is not clear in view of the striking hyperaldosteronism present. At the time of laparotomy, aldosterone secretion rates ranged from 0.041 to $0.168 \mu \mathrm{g}$ per minute, with a mean aldosterone secretion rate of $0.024 \pm 0.017 \mu \mathrm{g}$ per minute SD observed in normal dogs stressed by laparotomy $(t, 2.5 ; \mathrm{p}<0.02)$. The average corticosterone secretion rate was $2.28 \mu \mathrm{g}$ per minute, which is essentially the same as the value of $2.34 \pm 0.84 \mu \mathrm{g}$ per minute SD observed in normal dogs stressed by laparotomy.

It is noteworthy that in the two dogs in which the highest aldosterone secretion rates were ob-

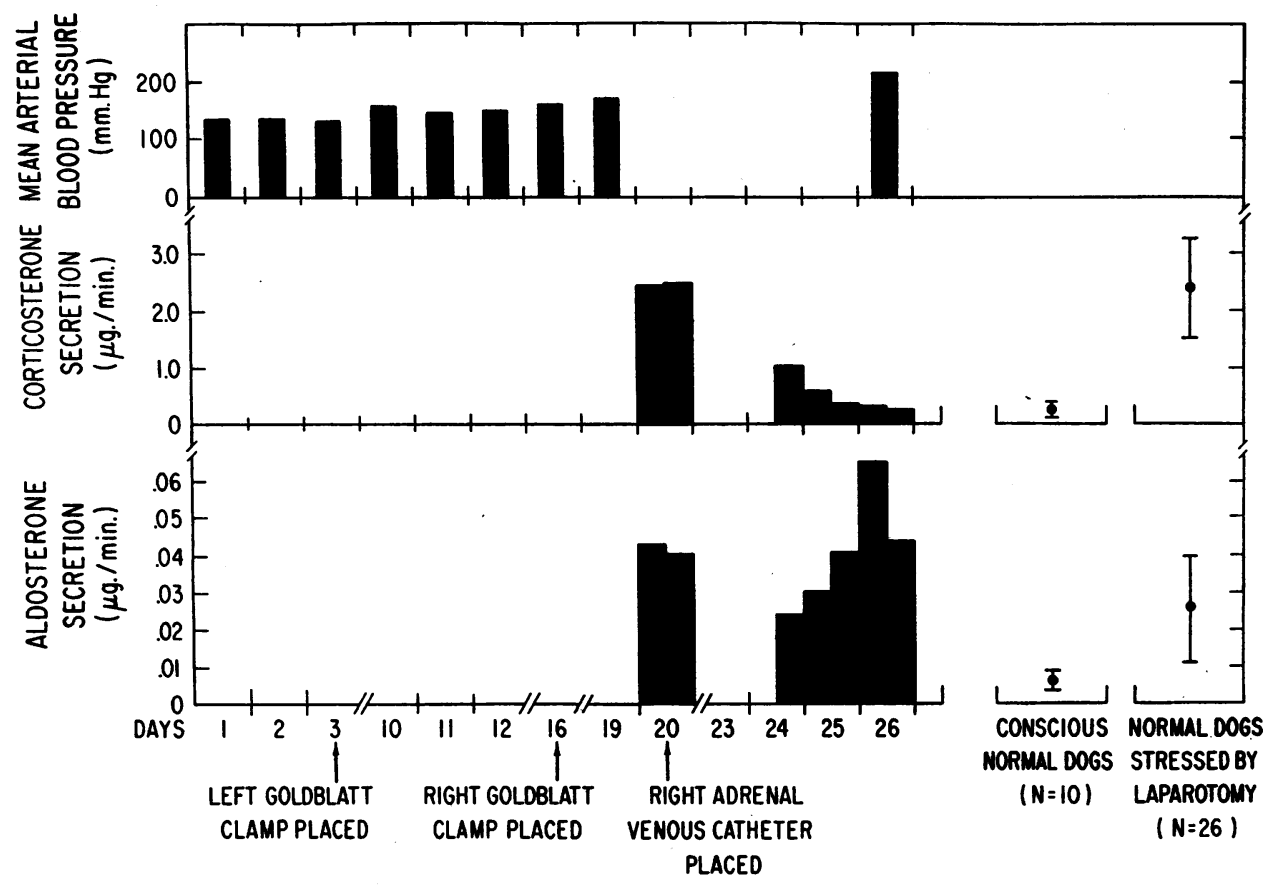

Fig. 4. Aldosterone and corticosterone secretion rates and mean arterial pressures IN A DOG IN THE MALIGNANT PHASE OF EXPERIMENTAL RENAL HYPERTENSION. Note the marked hypersecretion of aldosterone during the last two days of the study, at a time when corticosterone production has decreased to the basal level observed in conscious normal dogs (Dog 11 of Tables IV and V). 
served (Dogs 13 and 15 of Table IV), approximately $500 \mathrm{ml}$ of ascitic fluid was present at the time of adrenolumbar vein cannulation. A similar observation has subsequently been made in one additional animal with malignant renal hypertension. No ascites was present in either of the first two animals at the time of autopsy 3 days after laparotomy.

In the 4 dogs of the malignant hypertensive group in which adrenal effluent was collected for 3 to 8 days from the conscious animals via the indwelling adrenal venous catheter, the average aldosterone secretion rate was $0.070 \mu \mathrm{g}$ per minute. If the days on which corticosterone secretion exceeded $0.65 \mu \mathrm{g}$ per minute (i.e., the early postoperative days on which ACTH release greatly exceeded basal levels, presumably as a result of the stress of laparotomy) are excluded, the average aldosterone secretion rate was $0.067 \mu \mathrm{g}$ per minute, which represents a greater than 10-fold increase over the average value of $0.006 \mu \mathrm{g}$ per minute observed in normal unstressed, conscious dogs. Figure 4 presents data on the malignant hypertensive dog from which adrenal venous samples were collected for the longest period of time (Dog 11, Table IV). Note that at the time of laparotomy the corticosterone as well as the aldosterone secretion rate was elevated as a result of increased ACTH release secondary to the stress of surgery. However, during the last three days of collection, at a time when the animal was conscious, afebrile and unstressed, corticosterone output showed a progressive decline to the basal levels observed in normal conscious dogs; during this same period, aldosterone secretion rate, which was always at least four times the value observed in normal conscious dogs, showed a progressive increase to a maximal value eight times that observed in unstressed normal dogs. Similar observations were made in Dog 14 (Table V) in which aldosterone secretion progressively increased to a value of $0.080 \mu \mathrm{g}$ per minute on the final day of study, at which time the corticosterone output had decreased to a low basal level of $0.41 \mu \mathrm{g}$ per minute. The presence of this very high aldosterone secretion rate, in the presence of a low basal corticosterone output, indicates that the observed increment in aldosterone secretion was not dependent on increased ACTH release.

The average renin content (the product of the
TABLE VI

Aldosterone secretion rates and renin content of kidneys of dogs with benign and malignant hypertension

\begin{tabular}{|c|c|c|c|}
\hline \multirow[b]{2}{*}{ Dog } & \multicolumn{2}{|c|}{ Aldosterone secretion } & \multirow[b]{2}{*}{$\begin{array}{c}\text { Renin } \\
\text { content, } \\
\text { kidneys }\end{array}$} \\
\hline & $\begin{array}{l}\text { At lap)- } \\
\text { arotomy }\end{array}$ & $\begin{array}{l}\text { Via in- } \\
\text { dwelling } \\
\text { catheter } \\
\text { in consci- } \\
\text { ous, un- } \\
\text { stressed dogs }\end{array}$ & \\
\hline & \multicolumn{2}{|c|}{$\mu g / \min$} & $\underset{\text { kidneys }}{\operatorname{dog} U / 2}$ \\
\hline & \multicolumn{2}{|c|}{ Benign hypertension } & \\
\hline $\begin{array}{l}1 \\
2 \\
8 \\
X^{*}\end{array}$ & $\begin{array}{r}0.012 \\
.021 \\
.023\end{array}$ & $\begin{array}{r}0.007 \\
.002 \\
.004\end{array}$ & $\begin{array}{l}19 \\
38 \\
30 \\
28\end{array}$ \\
\hline \multirow[t]{2}{*}{ Average } & .019 & .004 & 29 \\
\hline & \multicolumn{2}{|c|}{ Malignant hypertension } & \\
\hline $\begin{array}{l}12 \\
13 \\
14 \\
15\end{array}$ & $\begin{array}{l}.044 \\
.066 \\
.043 \\
.168\end{array}$ & $\begin{array}{l}.079 \\
.076 \\
.087\end{array}$ & $\begin{array}{l}185 \\
178 \\
153 \\
125\end{array}$ \\
\hline \multirow[t]{2}{*}{ Average } & .080 & .081 & 160 \\
\hline & \multicolumn{2}{|c|}{ Normal dogs } & \\
\hline $\begin{array}{l}\text { Average } \\
\pm \mathrm{SD}\end{array}$ & $\begin{array}{c}.024 \\
\pm .017 \\
\mathrm{n}=26\end{array}$ & $\begin{array}{r}.006 \\
\pm .002 \\
\mathrm{n}=5\end{array}$ & $\begin{array}{l}15 \\
\pm 7.1 \\
n=7\end{array}$ \\
\hline
\end{tabular}

* Dogs are numbered as in Tables III, IV, and V, with the exception of Dog $\mathrm{X}$ which was an animal with benign renal hypertension of 2 months' duration, on which steroid secretion rates were not determined.

renin yield per gram of tissue and the total weight of both kidneys) of the two kidneys of the dogs with malignant renal hypertension was $160 \operatorname{dog} \mathrm{U}$ (range, 125 to 185 ), while the average renin content of the two kidneys of the dogs with benign renal hypertension was 29 dog U, (range, 19 to 38; Table VI). The difference between the benign and malignant hypertensive groups is highly significant statistically $(t, 7.37 ; \mathrm{p}<0.01)$. The average renin content of the kidneys of the dogs with benign hypertension was also greater than the renin content of the kidneys of normal dogs which had been maintained on the same synthetic diet and electrolyte intake for 5 to 10 days before the kidneys were removed (Table VI), but the difference was of borderline statistical significance $(t, 2.66 ; 0.05>\mathrm{p}>0.02)$.

\section{DISCUSSION}

The concept that aldosterone secretion is regulated by the renin-angiotensin system is derived from the findings of many investigators (1-14). 
This hypothesis was suggested by the indirect evidence that renin injections cause hypertrophy of the adrenal zona glomerulosa (6) and that the degree of granulation of the juxtaglomerular (JG) cells is directly correlated both with the amount of extractable renin in the kidney $(9,10,13)$ and with the width of the adrenal zona glomerulosa $(7,8,14)$. It has recently received strong support from the direct demonstration that an aldosterone-stimulating factor is secreted by the kidney (1-3) and that aldosterone-stimulating activity is confined to the renin fraction of crude kidney extracts (4). Tobian, after clearly summarizing the findings of many investigators in this field, $(13,14)$, has further postulated that the cells that produce renin, the JG cells $(25,26)$, located in the media of the renal afferent arterioles, act as baroreceptors responsive to the degree of filling of these vessels $(13,27)$. On the basis of this hypothesis, the JG cells would respond to decreased stretch of the renal afferent arterioles by an increase in renin secretion with a consequent augmentation of aldosterone output, and vice versa. Thus, the renin-angiotensin system, which appears to serve as a homeostatic mechanism in the maintenance of arterial blood pressure (28), could also perform a homeostatic function in the control of aldosterone secretion. The present experimental results are consistent with this concept.

The finding that infusion of very small quantities of renin increased the secretion rate of aldosterone in the hypophysectomized-nephrectomized dog adds support to the theory that the reninangiotensin system performs a physiological role in the control of aldosterone secretion. Although renin infusion in the present experiments resulted in increased production of corticosterone and Porter-Silber chromogens as well as aldosterone, the pattern of response was quite different from that seen during infusion of ACTH (29). Renin infusion increased the rate of aldosterone secretion to levels similar to those observed during infusion of $\mathrm{ACTH}$ in acutely hypophysectomized dogs (29) and after the stress of laparotomy in normal dogs (17). In marked contrast to these findings, the values during renin infusion for corticosterone and Porter-Silber chromogen output were approximately 10 and 2 per cent, respectively, of the values observed in normal dogs stressed by laparotomy $(17,24)$ and in hypophysectomized dogs given ACTH infusions (29). In fact, the secretion rates during renin infusion for corticosterone and Porter-Silber chromogens are essentially the same as the values observed in conscious, unstressed normal dogs with chronic adrenal venous catheters (24). Since it has been demonstrated (24) in studies on conscious dogs that corticosterone and Porter-Silber chromogen secretion rates may be low in the presence of a very high rate of aldosterone production (and presumably in the presence of increased quantities of the aldosterone-stimulating factor produced by the kidney), the results from the present renin infusion experiments are consistent with the concept that the renal aldosterone-stimulating factor is identical with renin.

The demonstration that angiotensin II also increases aldosterone output is in agreement with the previously reported findings of both Biron and associates (12) and Laragh, Angers, Kelly and Lieberman (11) that angiotensin II infusion consistently increases aldosterone production in man. The present results, obtained from hypophysectomized dogs, clearly demonstrate that angiotensin II increases aldosterone secretion by a non-ACTH mechanism, a finding that was suggested by the pattern of steroid secretion observed in the earlier studies in man $(11,12)$. The very marked increase in corticosterone observed in two of the four dogs which received the largest dose of angiotensin II would at first appear inconsistent with the hypothesis that the renin-angiotensin system regulates aldosterone secretion, since a maximal rate of aldosterone secretion is frequently observed in the presence of a very low basal corticosterone output in experimental secondary hyperaldosteronism (24). However, the rate of infusion of angiotensin II at the highest dosage level almost certainly exceeds the rate at which angiotensin II is released under physiological conditions (30). It is entirely possible that very great increases in activity of the renin-angiotensin system may cause appreciable increases in corticosterone as well as aldosterone. Indeed, one recent study (3) has demonstrated that nephrectomy of both hypophysectomized caval and hypophysectomized $\mathrm{Na}$ depleted dogs resulted in a marked decrease in corticosterone as well as aldosterone secretion, and that infusion of extracts of renal tissue from dogs 
with secondary hyperaldosteronism increased both corticosterone and aldosterone production.

The finding that the intermediate dosage of angiotensin II (the pressor effect of which was roughly equivalent to the pressor effect of the renin used in Experiment I) caused essentially the same qualitative changes in steroid secretion as did the renin infusion, suggests that renin exerts its effect on aldosterone secretion via angiotensin II. It is noteworthy that the increments in corticosterone (2- to 6-fold) and Porter-Silber chromogen ( 0 - to 4-fold) production observed during infusion of the intermediate dosage of angiotensin II are roughly comparable with the increments in cortisol and tetrahydrocortisol excretion (2- to 3fold) noted by Genest (31) during the infusion of angiotensin II in man at rates that caused moderate, sustained elevations of blood pressure. As pointed out by this investigator, increases in this magnitude of 17-hydroxycorticoids and of corticosterone are "small in terms of physiological significance" in comparison with the concomitant increases in aldosterone output that occurred during the angiotensin II infusion.

The results obtained after the infusion of 0.008 to $0.025 \mu \mathrm{g}$ per $\mathrm{kg}$ per minute of angiotensin II indicate that the minimal effective steroid-stimulating dose of angiotensin II may vary appreciably from animal to animal. Responses in aldosterone secretion occurred in the absence of an increase in blood pressure but never without a slight concomitant increase in corticosterone output. It has been reported by Genest (31), in regard to the response to angiotensin II infusions in man, that the minimal effective dose for blood pressure response exceeds the dose necessary to produce a measurable increase in aldosterone production. Although the present experimental data suggest that this situation may prevail in the dog, the present findings, obtained from anesthetized dogs which were hypophysectomized or hypophysectomized and nephrectomized, cannot be extrapolated with certainty to the conscious intact animal. Indeed, Goldblatt (32) has pointed out that the blood pressure response to renin in the barbiturate-anesthetized dog is markedly decreased as compared with the blood pressure response in normal conscious dogs.

Since the results from infusion of renin and angiotensin II support the hypothesis that aldo- sterone secretion is regulated by the renin-angiotensin system, the question arises as to the nature of the stimulus to renin production. Goldblatt, in his classic series of studies (32) showed that the renin content of the kidneys increased after bilateral renal arterial constriction; it was then postulated that diminished renal blood flow $(\mathrm{RBF})$ was the immediate stimulus to renin production. Corcoran and Page (33) subsequently showed that diminished renal blood flow was not invariably present in animals with experimental renal hypertension, and suggested that diminished pulse pressure in the renal arterioles provided the stimulus to renin production in these circumstances. However, later evidence (34) indicated that in animals with experimental renal hypertension secondary to encapsulation of the kidney, the intrarenal pulse pressure was increased rather than decreased. More recently Tobian (13) has pointed out that decreased stretch in the renal afferent arterioles (resulting in the clamped kidney from decreased renal arteriolar pressure, and in the encapsulated kidney from increased extrinsic pressure from the tissues surrounding the afferent arteriole) may be a common factor to both types of renal hypertension, and has postulated that decreased stretch provides the stimulus to increased renin production by the juxtaglomerular cells in both situations. This suggestion appears consistent with available data.

In the present experiments aldosterone secretion was increased above the normal range in only one of eight dogs with benign renal hypertension. This finding appears inconsistent with the concept that aldosterone secretion is regulated by the renin-angiotensin system, since earlier experiments indicated that increased production of renin is present in the majority of animals with renal hypertension during the first 3 months after bilateral renal arterial constriction $(16,32,35)$. Two explanations for this apparent inconsistency present themselves. In the first place, it is possible that increased renin secretion does not occur in the benign phase of experimental renal hypertension. Although increased renin content of the kidneys has appeared consistently to be present in previous studies of benign experimental and human essential hypertension $(16,32)$, increased renin secretion by the kidney in these situations has not been conclusively demonstrated in either 
man or $\operatorname{dog}(13,36,37)$. In the present dogs with benign experimental renal hypertension, the renin content of the kidneys, although greater that that found in normal dogs, was considerably lower than that observed in malignant renal hypertension. It is possible in benign experimental hypertension either that the hypertension is caused by increased sensitivity to small amounts of renin or that the hypertension is not solely dependent upon the renin-angiotensin system. In the second place, it is possible that the amount of renin secreted by the dogs with benign experimental hypertension, although increased to a level adequate to produce and maintain hypertension, is not adequate to cause hypersecretion of aldosterone. This latter alternative seems less likely in view of the previously cited findings of Genest (31) that angiotensin II infusion at a rate too low to elicit a blood pressure response augmented aldosterone output in man.

In the present study the dog in the benign hypertensive group in which the greatest rate of aldosterone production was noted (Dog 6 of Tables III and V) deserves special comment. This dog, alone among the animals in the benign group, appeared clinically to be developing malignant hypertension; beginning 3 days after the second Goldblatt clamp was placed (one day before the chronic adrenal catheter was inserted), he showed progressive lethargy, anorexia (but no vomiting despite forced feeding of diet) and weight loss. These symptoms persisted for 7 to 8 days, after which gradual improvement was observed. The symptoms coincided with the period during which hypersecretion of aldosterone was observed in this dog (during laparotomy and on Days 1-7 of Table V). It appears possible that both the malignant hypertensive symptoms and the hypersecretion of aldosterone were reflections of a marked increase in renin secretion resulting from a very substantial reduction in pressure in, or flow through, the renal afferent arterioles; and that both the symptomatic improvement and the decrease in aldosterone output resulted from the development of collateral renal arterial blood supply with a consequent decrease in renin production. In the present experiments extensive renal collateral vessels were observed within 10 days after application of the second Goldblatt clamp, and earlier studies (38) have demonstrated that re- nal blood flow may return to normal prehypertensive levels within 2 to 3 weeks after moderately severe constriction of the renal artery of a single explanted kidney.

The finding of consistent increases in aldosterone secretion rate in dogs with malignant hypertension is in agreement with the similar findings in man by Genest (39), Laragh (40) and Venning (41), and their co-workers and is entirely consonant with the hypothesis that the renin-angiotensin system performs a major role in the regulation of aldosterone secretion. The majority of reports indicate that renin secretion by the kidneys, as well as renin content of the kidneys, is increased in the malignant phase of both human essential and experimental renal hypertension $(13,30,35,42)$. This hypothesis is further supported by the present experimental finding that the renin content of the kidneys of the malignant hypertensive dogs, which exhibited marked hypersecretion of aldosterone, was greatly increased over the renin content in the benign hypertensive dogs in which aldosterone production was only slightly above the normal range.

Since the present experimental data are consistent with the hypothesis that aldosterone secretion is regulated by the renin-angiotensin system, the question arises as to why hypertension is not present in such situations as congestive heart failure, the post-hemorrhagic state, during thoracic inferior vena caval constriction, and during chronic $\mathrm{Na}$ depletion-conditions in which hypersecretion of aldosterone is a consistent finding $(1,3,43)$. Increased renin secretion has been reported in congestive heart failure (44) and after hemorrhage (45); and hyperplasia and hypergranulation of the juxtaglomerular cells, which provide presumptive evidence of increased renin production $(14,46)$, have recently been found after thoracic caval constriction (47) and during chronic $\mathrm{Na}$ depletion (9). The explanation may be that in these situations increased circulating angiotensin II, with a consequent increase in total peripheral resistance, serves to maintain a normal blood pressure. Thus, the renin-angiotensin system may act as a homeostatic mechanism $(8,28)$ to maintain an adequate flow of blood to vital organs under these circumstances. Recent observations that the blood pressure response to angiotensin II is greatly reduced in the 
dog during chronic $\mathrm{Na}$ depletion or during thoracic caval constriction (48) support this view. Available data therefore appear to be uniformly consistent with the hypothesis that the renin-angiotensin system plays an important role in the regulation of aldosterone production in a variety of circumstances in which hypersecretion of aldosterone is known to occur.

\section{SUMMARY AND CONCLUSIONS}

Infusion of renin into hypophysectomizednephrectomized dogs increased the rates of secretion of aldosterone, corticosterone and PorterSilber chromogens by a non-ACTH mechanism. Infusion of synthetic angiotensin II into hypophysectomized-nephrectomized or simple-hypophysectomized dogs (only anterior pituitary removed) likewise augmented the production of each of the steroids measured; a decrease in the rate of infusion of angiotensin II reduced the increment in corticosterone secretion to a far greater extent than the increment in aldosterone secretion. With doses of angiotensin II too small to elicit a blood pressure response, physiologically significant increases in aldosterone secretion were sometimes observed. At this very low dosage level, the increments in corticosterone output were quantitatively slightly greater than those of aldosterone but were at a level which usually has no physiological effect, and no significant changes in Porter-Silber chromogen production occurred. The renin content of the kidneys of dogs with benign renal hypertension was only slightly increased, and aldosterone secretion was within normal limits in these animals. A 10 -fold increase in the renin content of the kidneys was observed in dogs with malignant renal hypertension, and aldosterone output was markedly increased, by a non-ACTH mechanism, in this group of dogs. These data are consistent with the concept that the renin-angiotensin II system plays an important physiological role in the regulation of aldosterone secretion.

\section{ACKNOWLEDGMENTS}

Thanks are due to Dr. Harry Goldblatt and Dr. E. Haas, who gave considerable time to teach us their method for the extraction of renin. Acknowledgment is also due to Dr. Robert Gaunt of Ciba Pharmaceutical Products,
Inc., for the generous contribution of the angiotensin II used in the present study.

\section{REFERENCES}

1. Davis, J. O., Carpenter, C. C. J., Ayers, C. R., Holman, J. E., and Bahn, R. C. Evidence for secretion of an aldosterone-stimulating hormone by the kidney. J. clin. Invest. 1961, 40, 684.

2. Mulrow, P. J., and Ganong, W. F. The mechanism of aldosterone stimulation following hemorrhage in the hypophysectomized dog (abstract). J. clin. Invest. 1961, 40, 1065.

3. Davis, J. O., Ayers, C. R., and Carpenter, C. C. J. Renal origin of an aldosterone-stimulating hormone in dogs with thoracic caval constriction and in sodium-depleted dogs. J. clin. Invest. 1961, 40, 1466.

4. Davis, J. O., Titus, E. O., Ayers, C. R., Spiegel, H. E., and Carpenter, C. C. J. Fractionation of crude kidney extracts for aldosterone stimulating activity. Endocrine Society Abstracts. 1961, p. 13.

5. Carpenter, C. C. J., Davis, J. O., and Ayers, C. R. Relation of renin, hypertensin II and experimental renal hypertension to aldosterone secretion. Fed. Proc. 1961, 20, 178.

6. Deane, H. W., and Masson, G. M. C. Adrenal cortical changes in rats with various types of experimental hypertension. J. clin. Endocr. 1951, 11, 193.

7. Hartroft, P. M., and Hartroft, W. S. Studies on renal juxtaglomerular cells. II. Correlation of the degree of granulation of the juxtaglomerular cells with the width of the zona glomerulosa of the adrenal cortex. J. exp. Med. 1955, 102, 205.

8. Pitcock, J. A., and Hartroft, P. M. The juxtaglomerular cells in man and their relationship to the level of plasma sodium and to the zona glomerulosa of the adrenal cortex. Amer. J. Path. 1958, 34, 863 .

9. Hartroft, P. M., Newmark, L. N., and Pitcock, J. A. Relationship of renal juxtaglomerular cells to sodium intake, adrenal cortex and hypertension in Hypertension, J. H. Moyer, Ed. Philadelphia, Saunders, 1959, p. 24.

10. Gross, F. Renin und Hypertensin, physiologische oder pathologische Wirkstoffe? Klin. Wschr. 1958, 36, 693.

11. Laragh, J. H., Angers, M., Kelly, W. G., and Lieberman, S. Hypotensive agents and pressor substances. The effect of epinephrine, norepinephrine, angiotensin II, and others on the secretory rate of aldosterone in man. J. Amer. med. Ass. 1960, 174, 234.

12. Biron, P., Koiw, E., Nowaczynski, W., Brouillet, J., and Genest, J. Effects of intravenous infusion of valine-5-angiotensin II and other pressor agents 
on urinary electrolytes and corticosteroids, including aldosterone. J. clin. Invest. 1961, 40, 338.

13. Tobian, L. Interrelationship of electrolytes, juxtaglomerular cells and hypertension. Physiol. Rev. 1960, 40, 280.

14. Tobian, L. Physiology of the juxtaglomerular cells. Ann. intern. Med. 1960, 52, 395.

15. Goldblatt, H., Katz, Y. J., Lewis, H. A., and Richardson, E. Studies on experimental hypertension. XX. The bioassay of renin. J. exp. Med. 1943, 77, 309.

16. Haas, E., and Goldblatt, H. Renin content of kidneys in experimental renal and human essential hypertension. Amer. J. Physiol. 1959, 197, 1103.

17. Davis, J. O., Kliman, B., Yankopoulos, N. A., and Peterson, R. E. Increased aldosterone secretion following acute constriction of the inferior vena cava. J. clin. Invest. 1958, 37, 1783.

18. Kliman, B., and Peterson, R. E. Double isotope derivative assay of aldosterone in biological extracts. J. biol. Chem. 1960, 235, 1639.

19. Peterson, R. E., Karrer, A., and Guerra, S. L. Evaluation of Silber-Porter procedure for determination of plasma hydrocortisone. Analyt. Chem. 1957, 29, 144.

20. Goldblatt, H. Studies on experimental hypertension. $\mathrm{V}$. The pathogenesis of experimental hypertension due to renal ischemia. Ann. intern. Med. 1937, 11, 69.

21. Hume, D. M., and Nelson, D. H. Adrenal cortical function in surgical shock. Surg. Forum 1955, 5, 568.

22. Carpenter, C. C. J., Davis, J. O., Holman, J. E., Ayers, C. R., and Bahn, R. C. Studies on the response of the transplanted kidney and the transplanted adrenal gland to thoracic inferior vena caval constriction. J. clin. Invest. 1961, 40, 196.

23. Mulrow, P. J., and Ganong, W. F. Aldosterone secretion following hemorrhage in hypophysectomized dogs. J. clin. Invest. 1961, 40, 579.

24. Davis, J. O., Carpenter, C. C. J., Ayers, C. R., and Bahn, R. C. Relation of anterior pituitary function to aldosterone and corticosterone secretion in conscious dogs. Amer. J. Physiol. 1960, 199, 212.

25. Peart, W. S., Gordon, D. B., Cook, W. F., and Pickering, G. W. Distribution of renin in the rabbit kidney (abstract). Circulation 1956, 14, 981.

26. Cook, W. F., and Pickering, G. W. The location of renin within the kidney. J. Physiol. (Lond.) 1958, 143, 78P.

27. Tobian, L., Tomboulian, A., and Janecek, J. The effect of high perfusion pressures on the granulation of juxtaglomerular cells in an isolated kidney. J. clin. Invest. 1959, 38, 605.

28. Hamilton, A. S., and Collins, D.A. The homeostatic role of a renal humoral mechanism in hemorrhage and shock. Amer. J. Physiol. 1942, 136, 275.

29. Davis, J. O., Yankopoulos, N. A., Lieberman, F., Holman, J., and Bahn, R. C. The role of the anterior pituitary in the control of aldosterone secretion in experimental secondary hyperaldosteronism. J. clin. Invest. 1960, 39, 765.

30. Skeggs, L. T., Jr., and Kahn, J. R. Renal pressor system in hypertension: Evidence for circulating hypertensin in chronic renal hypertension-nature and activity of purified hypertensin. Circulation 1958, 17, 658.

31. Genest, J. Angiotensin, aldosterone and human arterial hypertension. Canad. med. Ass. J. 1961, 84, 403.

32. Goldblatt, H. The Renal Origin of Hypertension. Springfield, Ill., Thomas, 1948.

33. Corcoran, A. C., and Page, I. H. Renal blood flow in experimental hypertension due to constriction of the renal artery. Amer. J. Physiol. 1941, 133, 249P.

34. Swann, H. G., Prine, J. M., Moore, V., and Rice, R. D. The intrarenal pressure during experimental renal hypertension. J. exp. Med. 1952, 96, 281.

35. Wakerlin, G. E. Endocrine factors in renal hypertension. Physiol. Rev. 1955, 35, 555.

36. Blaquier, P., Bohr, D., Hoobler, S. W., and Green, $R$. A cross-circulation technique for the detection of circulating pressor substances in the hypertensive rat. Fed. Proc. 1959, 18, 12.

37. Peart, W. S. Hypertension and the kidney. II. Experimental basis of renal hypertension. Brit. med. J. 1959, 2, 1421.

38. Warthin, T. A., and Thomas, C. B. Studies in experimental hypertension. I. Phenol red excretion and renal blood flow in hypertension of renal origin. Bull. Johns Hopk. Hosp. 1943, 72, 203.

39. Genest, J., Koiw, E., Nowaczynski, W., and Leboeuf, G. Further studies on urinary aldosterone in human arterial hypertension. Proc. Soc. Exp. Biol. (N. Y.) 1958, 97, 676.

40. Laragh, J. H., Ulick, S., Januszewicz, V., Deming, Q. B., Kelly, W. G., and Lieberman, S. A1dosterone secretion in primary and malignant hypertension. J. clin. Invest. 1960, 39, 1091.

41. Venning, E. H., Dyrenfurth, I., Dossetor, J. B., and Beck, J. C. Essential hypertension and aldosterone. Circulation 1961, 23, 168.

42. Kahn, J. R., Skeggs, L. T., Jr., Shumway, N. P., and Wisenbaugh, P. E. Assay of hypertensin from arterial blood from normotensive and hypertensive human beings. J. exp. Med. 1952, 95, 523.

43. Davis, J. O., Pechet, M. M., Ball, W. C., Jr., and Goodkind, M. J. Increased aldosterone secretion in dogs with right-sided congestive heart failure and in dogs with thoracic inferior vena cava constriction. J. clin. Invest. 1957, 36, 689.

44. Merrill, A. J., Morrison, J. L., and Brannon, E. S. Concentration of renin in renal venous blood in patients with chronic heart failure. Amer. J. Med. 1946, 1, 468.

45. Dexter, L., Frank, H. A., Haynes, F. W., and Altschule, M. D. Traumatic shock. VI. The effect 
of hemorrhagic shock on the concentration of renin and hypertensinogen in the plasma in unanesthetized dogs. J. clin. Invest. 1943, 22, 847.

46. Pitcock, J. A., Hartroft, P. M., and Newmark, L. N. Increased renal pressor activity (renin) in sodium deficient rats and correlation with juxtaglomerular cell granulation. Proc. Soc. Exp. Biol. (N. Y.) $1959,100,868$.
47. Ayers, C. R., Hartroft, P. M., Carpenter, C. C. J., and Davis, J. O. Renal origin of the aldosterone stimulating hormone and hypergranulation of juxtaglomerular cells in experimental hyperaldosteronism. Endocrine Society Abstracts. 1961, p. 47.

48. Davis, J. O., Ayers, C. R., and Carpenter, C. C. J. Unpublished observations. 